\title{
Development of a DNA Metabarcoding Method for the Identification of Bivalve Species in Seafood Products
}

\author{
Kristina Gense ${ }^{1}$, Verena Peterseil ${ }^{2}$, Alma Licina ${ }^{3}$, Martin Wagner ${ }^{1,4}$, Margit Cichna-Mark1 ${ }^{5}(\mathbb{D}$, \\ Stefanie Dobrovolny ${ }^{2}$ and Rupert Hochegger $2, *$ (D) \\ 1 Austrian Competence Centre for Feed and Food Quality, Safety and Innovation, FFoQSI GmbH, \\ Technopark 1, 3430 Tulln an der Donau, Austria; kristina.gense@ffoqsi.at (K.G.); \\ martin.wagner@ffoqsi.at (M.W.) \\ 2 Austrian Agency for Health and Food Safety (AGES), Institute for Food Safety, \\ Department of Molecular Biology and Microbiology, Spargelfeldstr. 191, 1220 Vienna, Austria; \\ verena.peterseil@ages.at (V.P.); stefanie.dobrovolny@ages.at (S.D.) \\ 3 LVA GmbH, Magdeburggasse 10, 3400 Klosterneuburg, Austria; alma.licina@lva.at \\ 4 Department for Farm Animals and Veterinary Public Health, Institute of Milk Hygiene, \\ University of Veterinary Medicine, Veterinärplatz 1, 1210 Vienna, Austria \\ 5 Department of Analytical Chemistry, Faculty of Chemistry, University of Vienna, Währinger Straße 38, \\ 1090 Vienna, Austria; margit.cichna@univie.ac.at \\ * Correspondence: rupert.hochegger@ages.at
}

check for updates

Citation: Gense, K.; Peterseil, V.; Licina, A.; Wagner, M.; Cichna-Markl, M.; Dobrovolny, S.; Hochegger, R. Development of a DNA

Metabarcoding Method for the Identification of Bivalve Species in Seafood Products. Foods 2021, 10, 2618. https://doi.org/10.3390/ foods10112618

Academic Editor: Maria Castro-Puyana

Received: 28 September 2021

Accepted: 23 October 2021

Published: 28 October 2021

Publisher's Note: MDPI stays neutral with regard to jurisdictional claims in published maps and institutional affiliations.

Copyright: (c) 2021 by the authors. Licensee MDPI, Basel, Switzerland. This article is an open access article distributed under the terms and conditions of the Creative Commons Attribution (CC BY) license (https:// creativecommons.org/licenses/by/ $4.0 /)$.

\begin{abstract}
The production of bivalve species has been increasing in the last decades. In spite of strict requirements for species declaration, incorrect labelling of bivalve products has repeatedly been detected. We present a DNA metabarcoding method allowing the identification of bivalve species belonging to the bivalve families Mytilidae (mussels), Pectinidae (scallops), and Ostreidae (oysters) in foodstuffs. The method, developed on Illumina instruments, targets a $150 \mathrm{bp}$ fragment of mitochondrial $16 \mathrm{~S}$ rDNA. We designed seven primers (three primers for mussel species, two primers for scallop species and a primer pair for oyster species) and combined them in a triplex PCR assay. In each of eleven reference samples, the bivalve species was identified correctly. In ten DNA extract mixtures, not only the main component (97.0-98.0\%) but also the minor components (0.5-1.5\%) were detected correctly, with only a few exceptions. The DNA metabarcoding method was found to be applicable to complex and processed foodstuffs, allowing the identification of bivalves in, e.g., marinated form, in sauces, in seafood mixes and even in instant noodle seafood. The method is highly suitable for food authentication in routine analysis, in particular in combination with a DNA metabarcoding method for mammalian and poultry species published recently.
\end{abstract}

Keywords: DNA metabarcoding; next generation sequencing; food authentication; bivalves; Mytilidae; Pectinidae; Ostreidae; species identification; mitochondrial 16S rDNA; seafood

\section{Introduction}

Bivalves, a class of molluscs, are distributed worldwide. Due to their high content of essential nutrients, their production has steadily been increased over the last three decades [1-5]. Mytilidae (mussels), Pectinidae (scallops), and Ostreidae (oysters) are the most important bivalve families for human consumption. Each of these bivalve families is divided into several genera comprising a high number of species [6]. In 2019, 1.03 million tons of mussels, scallops, and oysters were caught in nature and 10.25 million tons were cultivated in aquaculture, earning a profit of millions of US dollars [7].

In the EU, international and national regulations exist to ensure legal trade in seafood and seafood products. The EU directive 1379/2013 regulates market organization of fishery and aquaculture products, including correct declaration of seafood [8]. To comply with legal regulations, labels must include both the local trade name in the official language(s) and the correct scientific Latin name [8,9]. Correct labelling of seafood products is important 
for traceability issues, protection of endangered species, mitigation of illegal fishing, and for individual reasons of end consumers [10,11]. Regardless of clear and strict requirements for species declaration, incorrect labelling of bivalve products has repeatedly been detected in Europe [12-17]. In German and Swiss studies, more than half of the products declared to contain "Jakobsmuschel" (or "Jacobsmuschel") were labelled incorrectly [15,18,19]. Although the German name "Jakobsmuschel" (or "Jacobsmuschel") may only be used for scallop species belonging to the genus Pecten, species of other genera (particularly Placopecten and Mizuhopecten) were identified in these products.

For authentication of seafood products, laboratories may choose from a variety of methodologies. In the case of bivalves, morphological characteristics such as shell, color, and size may allow correct species classification. However, after shell removal or mechanical processing, classification by morphology may be hampered or even be impossible $[16,20]$. Recently, matrix-assisted laser desorption ionization time of flight mass spectrometry (MALDI-TOF MS) has been shown to be suitable for accurate species identification of scallops [19]. However, since MALDI-TOF MS instruments are rather expensive and do not allow high-throughput analysis, this methodology is less applicable for routine analyses.

To date, DNA-based methods are considered most suitable for the identification of seafood species, even in highly processed food products [21-23]. Due to its high copy number and robustness, mitochondrial DNA (mtDNA) is frequently preferred over genomic DNA [24,25]. The mtDNA regions most commonly used for species identification are cytochrome c oxidase subunit I (COI), cytochrome b (cyt b), and 16S ribosomal DNA (16S rDNA) [15,26-33]. Compared to other seafood, e.g., fish, crustaceans, and cephalopods, (real-time) polymerase chain reaction (PCR) assays for bivalve species are limited in number [18,32,34-41]. The disadvantage of (real-time) PCR is that for each target species, a specific primer (probe) system is required [18,31,33,36,39-43].

A powerful alternative is DNA barcoding, aiming at detecting a broader range of species by using universal primer systems [22,26,34,44]. DNA barcodes commonly contain conserved regions at both ends, serving as binding sites for universal primers, and a variable part in between the primer binding sites, for differentiation between the species of interest $[34,45]$. DNA barcodes of approximately 600 base pairs (bp) in length have been found to be suitable for the analysis of highly processed food products [22,26,27,34,44,46-48]. In conventional DNA barcoding, PCR products obtained by amplifying the selected DNA barcode region are then subjected to Sanger sequencing [22,34,44,49,50]. However, sample throughput of Sanger sequencing is limited since samples are sequenced one by one. A much more efficient approach is to combine DNA barcoding with next-generation sequencing (NGS) technologies $[22,26,34]$. So-called DNA metabarcoding allows the identification of multiple species in multiple food samples in one and the same sequencing run $[45,46,51-54]$. The suitability of DNA metabarcoding for the analysis of ultra-processed food products has already been demonstrated, e.g., for the detection of mammals in sausages or insects in bars $[47,48]$.

In this study, we present a DNA metabarcoding method allowing the differentiation between species from three bivalve families, Pectinidae, Ostreidae, and Mytilidae, in raw and processed food products to detect food adulteration. The method was developed on the Illumina MiSeq ${ }^{\circledR}$ (San Diego, CA, USA) and iSeq ${ }^{\circledR}$ (San Diego, CA, USA) platforms due to their low error rates compared to other NGS platforms [55].

\section{Materials and Methods}

\subsection{Sample Collection and Storage}

A total of 86 commercial food products were collected from regional supermarkets, fish markets, and delicacy shops in Austria from summer 2018 until winter 2020 (Supplementary Table S1). Samples were either fresh, deep-frozen, or in processed condition. Each sample was given a specific ID number, with the letter " $\mathrm{O}$ " referring to oysters, " $\mathrm{S}$ " to scallops, "M" to mussels, and "Mi" to mixed-species seafood. Samples were stored at $-20{ }^{\circ} \mathrm{C}$ until DNA extraction. 
Eleven out of the 86 samples ("reference samples"), comprising three mussel, six scallop, and two oyster species (see Table 1), were used for method development. Identity of bivalve species in these reference samples (samples M12, M13 and M27 for mussels; samples S42, S46, S47, S49, S50, and S55 for scallops; samples O2 and O3 for oysters; Supplementary Table S1) was verified by subjecting DNA extracts to Sanger sequencing (Microsynth, Balgach, Switzerland) and matching the sequences against the public databases provided by the National Center for Biotechnology Information (NCBI, Bethesda, MD, USA). For Sanger sequencing, the forward and reverse primers listed in Table 2 were used.

Table 1. Bivalve species used for development of the DNA metabarcoding method.

\begin{tabular}{ccc}
\hline Scientific Name & Commercial Name (German) & Commercial Name (English) \\
\hline Mytilidae & Miesmuscheln & Mussels \\
\hline Mytilus edulis & Gemeine Miesmuschel & Blue mussel \\
Mytilus galloprovincialis & Mittelmeer-Miesmuschel & Mediterranean mussel \\
Perna canaliculus & Neuseeland-Miesmuschel & New Zealand green-lipped mussel \\
\hline Pectinidae & Kammmuscheln & Scallops \\
\hline Placopecten magellanicus & Atlantischer Tiefseescallop & Atlantic deep-sea scallop \\
Mizuhopecten yessoensis & Yesso scallop \\
Pecten jacobaeus & Japanische Kammmuschel & Great scallop \\
Zygochlamys patagonica & Jakobsmuschel & Patagonian scallop \\
Argopecten purpuratus & Purple scallop \\
Aequipecten opercularis & Patagonische Kammmuschel & Queen scallop \\
\hline Ostreidae & Purpur-Kammmuschel & Oysters \\
\hline Magallana gigas & Kleine Pilgermuschel & Pacific oyster \\
Ostrea edulis & Austern & European flat oyster \\
\hline
\end{tabular}

Table 2. Primers designed in this study.

\begin{tabular}{cr}
\hline Name & Sequence $\mathbf{5}^{\prime} \rightarrow \mathbf{3}^{\prime}$ \\
\hline mussel & \\
\hline For_Mu & CCTTTTGCATAAGGGTTTTTCAAG \\
\hline Rev1_Mu & CGAATAGTATCTAGCCGCCATTC \\
\hline Rev2_Mu & GCAAATAGCATATCACTTTCACCTC \\
\hline scallop & \\
\hline For_Mu & TGCTAAGGTAGCTAAATTATGGCC \\
\hline Rev_Mu & CTTCACGGGGTCTTCTCGTC \\
\hline oyster & \\
\hline For_Mu & GGTAGCGAAATTCCTTGCCTT \\
\hline Rev_Mu & AAAGTTGCACGGGGTCTT \\
\hline overhang & \\
\hline Forward & TCGTCGGCAGCGTCAGATGTGTATAAGAGACAG \\
\hline Reverse & GTCTCGTGGGCTCGGAGATGTGTATAAGAGACAG
\end{tabular}

\subsection{DNA Extraction and Quantification}

Raw material was cut into smaller pieces or homogenized. To $2.0 \mathrm{~g}$ of each sample, $10 \mathrm{~mL}$ of a hexadecyltrimethylammonium bromide (CTAB) buffer was added. After addition of $80 \mu \mathrm{L}$ proteinase $\mathrm{K}$, the mixture was incubated on an Intelli-Mixer ${ }^{\mathrm{TM}} \mathrm{RM} 2$ (LTF Labortechnik, Wasserburg, Germany) overnight at $50{ }^{\circ} \mathrm{C}$. 
For DNA isolation, a commercial kit (Maxwell ${ }^{\circledR} 16$ FFS Nucleic Acid Extraction System Custom-Kit, Promega, Madison, WI, USA) was used according to the manufacturer's instructions. DNA concentration was determined fluorometrically (Qubit ${ }^{\circledR} 2.0$ fluorometer, Thermo Fisher Scientific, Waltham, MA, USA). For higher concentrations, the Qubit ${ }^{\circledR}$ dsDNA broad range assay kit (2 to $1000 \mathrm{ng}$ ) was used, and for lower concentrations, the Qubit ${ }^{\circledR}$ dsDNA high-sensitivity assay kit (0.2 to $100 \mathrm{ng}$ ) was used. DNA purity was assessed from the ratio of the absorbance at 260 and $280 \mathrm{~nm}$ (QIAxpert spectrophotometer, software version 2.2.0.21, Qiagen, Hilden, Germany). DNA extracts were stored at $-20{ }^{\circ} \mathrm{C}$ until further use.

\subsection{DNA Extract Mixtures}

Ternary DNA extract mixtures were prepared by mixing DNA extracts (DNA concentration $5 \mathrm{ng} / \mu \mathrm{L}$ ) from Pecten spp., Magallana gigas and Mytilus galloprovincialis, representing the three bivalve families Pectinidae, Ostreidae, and Mytilidae, respectively. Individual DNA extracts were mixed in a ratio of 98.0:1.5:0.5 $(v / v / v)$.

In addition, DNA extract mixtures consisting of DNA from species belonging to one bivalve family were prepared. In these mixtures, DNA from one species was present as the main component, DNA from the other species as minor components (1.0\% each). Since only two oyster species were available, the DNA extract mixture representing the bivalve family Ostreidae contained the closely related scallop (Placopecten magellanicus) as a major component $(98.0 \%)$ and DNA from the two oyster species as minor components (1.0\% each).

In addition to mixtures consisting of DNA from bivalve species only, a DNA extract mixture containing another mollusc species was prepared. DNA extract from a squid species (Sepiella inermis) was chosen as the main component $(97.0 \%)$ and DNA from the bivalve species Placopecten magellanicus, Ostrea edulis and Perna canaliculus was present as minor components (1.0\% each).

\subsection{Reference Sequences}

A $150 \mathrm{bp}$ fragment of the mitochondrial 16S rDNA gene was used as a DNA barcode. Reference sequences for commonly consumed bivalve species and some exotic seafood species, that are permitted for consumption in Austria ("Codex Alimentarius Austriacus" chapter B35, [56]), were downloaded from the NCBI databases (Supplementary Table S2) by using CLC Genomics Workbench software (version 10.1.1, Qiagen, Hilden, Germany). If available, complete reference sequences from the RefSeq database were preferentially downloaded due to their reliability. In case complete reference sequences were not available, all DNA sequences of the mitochondrial $16 \mathrm{~S}$ rDNA available for one and the same species, submitted by individual scientists, were aligned and checked for similarity and unidentified nucleotides. Subsequently, the DNA sequence with the highest quality (e.g., without unknown nucleotides, full-length of the DNA barcode) was chosen as a reference sequence.

\subsection{Primer Systems}

Primers were designed manually on a multiple DNA sequence alignment of the mitochondrial $16 \mathrm{~S}$ rDNA of approximately 90 bivalve species using the CLC Genomics Workbench software (version 10.1.1, Qiagen, Hilden, Germany). The designed primers were checked for their physical and structural properties (e.g., formation of dimers, secondary structure, annealing temperature) using Oligo Calc, the OligoAnalyzer Tool provided by Integrated DNA Technologies (IDT, Coralville, IA, USA) and the online product descriptions from TIB Molbiol (Berlin, Germany). The primers, listed in Table 2, were synthesized by TIB Molbiol. Table 2 also shows the Illumina overhang adapter sequences which were linked to the target-specific primers.

All in-house-designed primers were tested in real-time PCR with DNA extracted from the eleven reference samples. During optimization, the following PCR conditions/parameters were kept constant and applied as published previously: DNA input amount of $12.5 \mathrm{ng}$, 'ready-to-use' HotStarTaq Master Mix Kit, annealing temperature $\left(62{ }^{\circ} \mathrm{C}\right), 25$ cycles [47]. 
Only one variable, the addition of magnesium chloride solution, was modified (addition of 1.5 or $3 \mathrm{mM} \mathrm{MgCl}$ ). Real-time PCR reactions were carried out using a fluorescent intercalating dye (EvaGreen ${ }^{\circledR}(20 \mathrm{x}$ in water)) in strip tubes or in 96-well plates, depending on the thermocycler used, the Rotor-Gene Q (Qiagen, Hilden, Germany) or the LightCycler ${ }^{\circledR}$ 480 System (Roche, Penzberg, Germany), respectively. The total volume of the PCR reactions was $25 \mu \mathrm{L}$, consisting of $22.5 \mu \mathrm{L}$ reaction mix and $2.5 \mu \mathrm{L}$ of template DNA (diluted DNA samples $(5 \mathrm{ng} / \mu \mathrm{L})$ ) or water as negative control. In the reaction mix, the HotStarTaq Master Mix Kit (Qiagen, Hilden, Germany) was used at a final concentration of $1 \mathrm{x}$ and the final concentration of primers was $0.2 \mu \mathrm{M}$, except the forward primer for mussels $(0.4 \mu \mathrm{M})$. PCR cycling conditions were $15 \mathrm{~min}$ initial denaturation at $95^{\circ} \mathrm{C}, 25$ cycles at $95^{\circ} \mathrm{C}$, $62{ }^{\circ} \mathrm{C}$ and $72{ }^{\circ} \mathrm{C}$ for $30 \mathrm{~s}$ each, and a final elongation for $10 \mathrm{~min}$ at $72{ }^{\circ} \mathrm{C}$. The primer pairs for mussels, scallops, and oysters with and without Illumina overhang adapter sequences were first used in singleplex PCR assays. Then, the seven primers (three forward and four reverse primers) listed in Table 2 were combined in a triplex assay. The identity of the PCR products was confirmed by melting curve analysis and/or agarose gel electrophoresis.

\subsection{Library Preparation and NGS}

In general, samples were sequenced by using either the $\mathrm{MiSeq}^{\circledR}$ or the iSeq ${ }^{\circledR}$ platform (Illumina, San Diego, CA, USA). DNA extracts were diluted to a DNA concentration of $5 \mathrm{ng} / \mu \mathrm{L}$. Extracts with a DNA concentration $<5 \mathrm{ng} / \mu \mathrm{L}$ were used undiluted.

DNA library preparation was performed according to Dobrovolny et al. [47] with minor modifications (excess of $\mathrm{MgCl}_{2}$, final concentration $3 \mathrm{mM}$; average library size: $278 \mathrm{bp}$; diluted libraries of the iSeq ${ }^{\circledR}$ system were denatured automatically on the instrument).

For the MiSeq ${ }^{\circledR}$ and iSeq ${ }^{\circledR}$ platform, the DNA library was adjusted to 4 and $1 \mathrm{nM}$, respectively, with $10 \mathrm{mM}$ Tris- $\mathrm{HCl}, \mathrm{pH}$ 8.6. After pooling individual DNA libraries $(5 \mu \mathrm{L}$ MiSeq $^{\circledR}, 7 \mu \mathrm{L}$ iSeq ${ }^{\circledR}$ ), the DNA concentration was determined using Qubit ${ }^{\circledR} 2.0$ fluorimeter.

All sequencing runs were performed using either the MiSeq ${ }^{\circledR}$ Reagent Kit v2 (300-cycles) or the iSeq ${ }^{\circledR} 100$ i1 Reagent v2 (300-cycles) with a final loading concentration of 8 pM. The pooled DNA libraries contained a 5\% PhiX spike-in.

Reference samples were sequenced in six replicates (three sequencing runs, two replicates per run), while DNA extract mixtures were sequenced in nine replicates (three sequencing runs, three replicates per run). Commercial food products were sequenced in triplicates (three sequencing runs, one replicate per run) and food products were sequenced at least once by using either the MiSeq ${ }^{\circledR}$ or the iSeq ${ }^{\circledR}$ platform.

\subsection{NGS Data Analysis Using Galaxy}

After paired-end sequencing, the resulting FastQ files, generated by the instrument control software, were used as input for data analysis. The sequencing output in FastQ format was then processed with an analysis pipeline as described previously by using Galaxy (version 19.01) [47]. The published amplicon analysis workflow was modified as follows: the target-specific primers were trimmed from both ends using the tool Cutadapt and reads were not clustered into Operational Taxonomic Units (OTUs) [57]. Completely identical sequences were collapsed into a single representative sequence with the tool Dereplicate to minimize the number of reads, and then compared against a customized database for bivalves (Supplementary Table S2) using BLASTn [58].

\section{Results and Discussion}

\subsection{Barcode Region and Primer Systems}

We aimed to develop a DNA metabarcoding method allowing the differentiation between species belonging to the bivalve families Pectinidae, Ostreidae, and Mytilidae. To be applicable in routine analysis, the method should allow identifying the economically most important bivalve species in raw and highly processed food products.

We started with searching for appropriate DNA barcode regions of about $150 \mathrm{bp}$ in length, containing conserved parts at the ends and a variable part in between. Potential 
DNA barcode regions were found in the mitochondrial DNA, especially the mitochondrial $16 S$ rDNA. Several metabarcoding studies have shown that the sequences of the 16S rDNA gene are suitable as barcodes for species identification. Since we have already used a barcode region of the mitochondrial $16 \mathrm{~S}$ rDNA to identify mammals and poultry [47], this marker gene was chosen as the DNA barcode for our assay.

Since the DNA metabarcoding method for bivalves should be compatible with the DNA metabarcoding method for mammalian and poultry species published recently [47], the primers should anneal at the same temperature $\left(62^{\circ} \mathrm{C}\right)$. In addition, the PCR cycle number should be limited to 25 and DNA libraries should be sequenced with Illumina reagent kits in the 300-cycle format. Due to high sequence variability between closely related bivalve species, none of the primer sets designed enabled obtaining a PCR product for each of the bivalve species of interest. Thus, we continued by designing three primer sets, one for each of the three bivalve families, Pectinidae, Ostreidae, and Mytilidae. Primer pairs consisting of one forward and one reverse primer allowed amplifying the DNA barcode region in scallop and oyster species (Table 2). However, in the case of mussels, a primer set consisting of one forward primer and two reverse primers (Table 2) was necessary to obtain a PCR product for the mussel species listed in Table 1. Figure 1 shows an alignment of selected DNA barcode sequences for the commercially most relevant bivalve species. The alignment of the 90 bivalve species is shown in Supplementary Figure S1. Blue, green, and red bars indicate the binding sites of the primers for Pectinidae, Ostreidae and Mytilidae, respectively. With the three primer sets, PCR products differing in at least one base should be obtained for all bivalve species of interest.

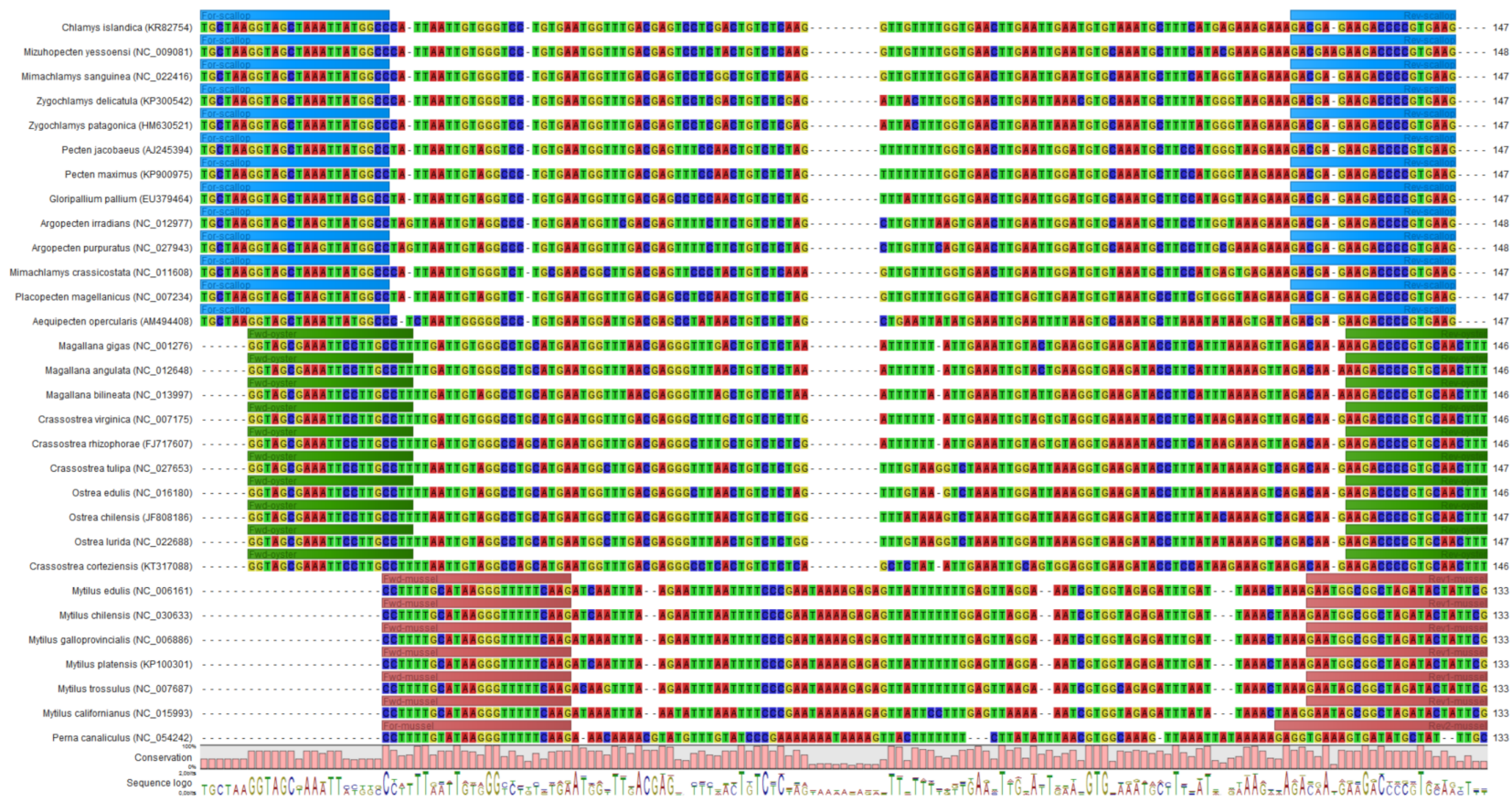

Figure 1. Multi-species sequence alignment of the mitochondrial $16 \mathrm{~S}$ rDNA barcoding region for bivalve species. Colored bars indicate the binding sites of the primer sets for scallops (blue), oysters (green), and mussels (red, CLC Genomics Workbench software version 10.1.1, Qiagen, Hilden, Germany).

Further sequence alignments indicated that the DNA barcode region selected does not allow distinguishing between all species of the following genera: Chlamys spp., Euvola spp., Pecten spp., Crassostrea spp., Magallana spp., Ostrea spp. and Saccostrea spp. These species cannot be distinguished: Chlamys rubida and Chlamys behringiana; Pecten albicans, Pecten fumatus, Pecten jacobaeus, Pecten keppelianus, Pecten novaezelandiae, Pecten sulcicostatus, Crassostrea hongkongensis, and Crassostrea rivularis; Ostrea angelica and Ostrea lurida; as well as Ostrea permollis and Ostrea puelchana; and Saccostrea echinata, Saccostrea glomerata, and 
Saccostrea mytiloides. In addition, two mussel species, Mytilus platensis and Mytilus chilensis, can also not be distinguished (for Mytilus platensis only one DNA sequence entry was in the public databases provided by NCBI). However, differentiation at the genus level (Chlamys spp., Pecten spp., Crassostrea spp., Ostrea spp., Mytilus spp.) is sufficient according to the "Codex Alimentarius Austriacus" chapter B35 [56].

When we tested the primers in singleplex PCR assays, for each of the reference samples a PCR product of about $150 \mathrm{bp}$ in length was obtained by increasing the concentration of the forward primer for mussels to $0.4 \mu \mathrm{M}$ and keeping the concentration of the other six primers at $0.2 \mu \mathrm{M}$. In addition, we tested whether the seven primers could be combined to a triplex system. PCR products for the bivalve species of interest were obtained in one and the same vial by increasing the $\mathrm{MgCl}_{2}$ concentration to a final concentration of $3 \mathrm{mM}$. Thus, we achieved our objective to perform the triplex PCR assay in combination with the previously published DNA metabarcoding assay for mammalian and poultry species [47].

\subsection{Library Preparation, Pooling of Libraries, and Sequencing}

Library preparation, pooling of 5 or $7 \mu \mathrm{L}$ per normalized DNA library, and the sequencing process were performed as described previously [47]. However, in case of the pooling process, all DNA libraries were mixed in equal volumes as recommended by the manufacturer's instruction. In our previous study, different volumes from individual DNA libraries were taken to achieve sufficient sequencing depth for minor components. For sample pooling to the maximum of 96 libraries, more than 100,000 NGS reads per sample were expected to be obtained using the 300 -cycle MiSeq ${ }^{\circledR}$ Reagent Kit v2.

Sequencing runs were performed in triplicate and the average run metrics were as follows: cluster density $\left(969 \mathrm{~K} / \mathrm{mm}^{2}\right)$ on the flow cell, cluster passing filter $(70.22 \%)$ as well as the Q-scores (Q30) for read 1 and read 2 were $92.6 \%$ and $89.28 \%$, respectively. A total of $5.02 \%$ of the total reads were identified as PhiX control sequences with an error rate of $1.49 \%$.

\subsection{Analysis of DNA Extracts from Reference Samples}

PCR products were obtained for each of the reference samples and sequencing results for those samples are summarized in Table 3. The table shows mean values of the total number of raw reads, the total number of reads that passed the analysis pipeline in Galaxy as well as the total number and percentage of reads that were assigned correctly to the eleven species (based on six replicates).

No significant differences were observed in the total number of reads (before data analysis process) between these species, except Mytilus galloprovincialis (162843), Perna canaliculus (169631), and Mytilus edulis (134500). With the exception of Perna canaliculus, $>70 \%$ of the reads passed the amplicon analysis workflow. All three mussel species, six scallop species and two oyster species could be identified with this workflow at a high rate (>97.5\%), except Mytilus edulis.

\subsection{Analysis of DNA Extract Mixtures}

Six ternary DNA extract mixtures were analyzed containing the DNA of the three bivalve families Pectinidae, Ostreidae, and Mytilidae in ratios of 98.0:1.5:0.5 $(v / v / v)$. The composition of the DNA extract mixtures and the results obtained by DNA metabarcoding are summarized in Table 4 . The total number of raw reads ranged from 80856 to 159,737 and the reads that passed the workflow were in the range from 65961 to 147196 . For the main components $(98.0 \%)$, the number of reads assigned correctly ranged from 62434 to 140147 . In addition, both minor components $(1.5 \%$ and $0.5 \%)$ could be identified. The number of reads assigned correctly was in the range from 1710 to 4356 and 555 to 1478, respectively. 
Table 3. Results for DNA extracts from reference samples. Numbers are mean values $(n=6$, three sequencing runs, two replicates per run).

\begin{tabular}{|c|c|c|c|c|c|c|c|}
\hline \multirow[b]{2}{*}{ Sample ID } & \multicolumn{2}{|c|}{ Declaration on the Product } & \multirow[b]{2}{*}{$\begin{array}{l}\text { Species } \\
\text { Identified }\end{array}$} & \multirow[b]{2}{*}{$\begin{array}{l}\text { Total Number } \\
\text { of Raw Reads }\end{array}$} & \multirow{2}{*}{$\begin{array}{l}\text { Total Number } \\
\text { of Reads } \\
\text { Passing the } \\
\text { Workflow }\end{array}$} & \multirow{2}{*}{$\begin{array}{l}\text { Number of } \\
\text { Reads } \\
\text { Assigned } \\
\text { Correctly }\end{array}$} & \multirow{2}{*}{$\begin{array}{l}\text { Percentage of } \\
\text { Reads } \\
\text { Assigned } \\
\text { Correctly (\%) }\end{array}$} \\
\hline & $\begin{array}{c}\text { Scientific/Latin } \\
\text { Name }\end{array}$ & $\begin{array}{c}\text { Product } \\
\text { Description } \\
\text { [Eng] }\end{array}$ & & & & & \\
\hline $\mathrm{O} 2$ & Ostrea edulis & Oyster & Ostrea edulis & 78559 & 63491 & 61875 & 97.46 \\
\hline $\mathrm{O} 3$ & $\begin{array}{l}\text { Crassostrea } \\
\text { gigas * }\end{array}$ & Oyster & Magallana gigas * & 76143 & 65389 & 64125 & 98.07 \\
\hline M12 & $\begin{array}{c}\text { Mytilus } \\
\text { galloprovincialis }\end{array}$ & Blue Mussel & $\begin{array}{c}\text { Mytilus } \\
\text { galloprovincialis }\end{array}$ & 162843 & 150678 & 149315 & 99.09 \\
\hline M13 & $\begin{array}{c}\text { Perna } \\
\text { canaliculus }\end{array}$ & $\begin{array}{l}\text { New Zealand } \\
\text { green-lipped } \\
\text { mussel }\end{array}$ & Perna canaliculus & 169631 & 104861 & 103350 & 98.56 \\
\hline M27 & Mytilus edulis & $\begin{array}{l}\text { Mussels in } \\
\text { marinade }\end{array}$ & Mytilus edulis & 134500 & 120686 & 105024 & 87.02 \\
\hline S42 & $\begin{array}{c}\text { Mizuhopecten } \\
\text { yessoensis }\end{array}$ & Yesso scallop & $\begin{array}{c}\text { Mizuhopecten } \\
\text { yessoensis }\end{array}$ & 75927 & 58069 & 57058 & 98.26 \\
\hline S46 & Pecten jacobaeus & Great scallop & Pecten spp. & 79472 & 61484 & 60514 & 98.42 \\
\hline S47 & $\begin{array}{l}\text { Zygochlamys } \\
\text { patagonica }\end{array}$ & $\begin{array}{l}\text { Scallop "á la } \\
\text { Bretonne" }\end{array}$ & $\begin{array}{l}\text { Zygochlamys } \\
\text { patagonica }\end{array}$ & 77747 & 59245 & 58429 & 98.62 \\
\hline S49 & $\begin{array}{l}\text { Placopecten } \\
\text { magellanicus }\end{array}$ & Great scallop & $\begin{array}{l}\text { Placopecten } \\
\text { magellanicus }\end{array}$ & 79131 & 61531 & 60886 & 98.95 \\
\hline S50 & $\begin{array}{l}\text { Argopecten } \\
\text { purpuratus }\end{array}$ & Pacific scallop & $\begin{array}{l}\text { Argopecten } \\
\text { purpuratus }\end{array}$ & 77383 & 55455 & 54588 & 98.44 \\
\hline S55 & $\begin{array}{l}\text { Aequipecten } \\
\text { opercularis }\end{array}$ & $\begin{array}{l}\text { Scallop in } \\
\text { sauce }\end{array}$ & $\begin{array}{l}\text { Aequipecten } \\
\text { opercularis }\end{array}$ & 79141 & 56064 & 55800 & 99.53 \\
\hline
\end{tabular}

* former nomenclature, synonym for Magallana gigas.

Table 4. Results for ternary DNA extract mixtures representing the three bivalve families of interest. DNA extracts $(5 \mathrm{ng} / \mu \mathrm{L})$ were mixed in a ratio of 98.0:1.5:0.5 $(v / v / v)$. Numbers are mean values $(n=9$, three sequencing runs, three replicates per run).

\begin{tabular}{|c|c|c|c|c|c|c|c|c|c|c|}
\hline \multicolumn{3}{|c|}{ Proportion } & \multirow{2}{*}{$\begin{array}{c}\text { Total } \\
\text { Number } \\
\text { of Raw } \\
\text { Reads }\end{array}$} & \multirow{2}{*}{$\begin{array}{l}\text { Total Number } \\
\text { of Reads } \\
\text { Passing the } \\
\text { Workflow }\end{array}$} & \multicolumn{6}{|c|}{ Reads Assigned Correctly } \\
\hline Species $1(98 \%)$ & $\begin{array}{c}\text { Species } 2 \\
(1.5 \%)\end{array}$ & $\begin{array}{c}\text { Species } 3 \\
(0.5 \%)\end{array}$ & & & Species 1 & $(\%)$ & Species 2 & $(\%)$ & Species 3 & $(\%)$ \\
\hline $\begin{array}{l}\text { Magallana } \\
\text { gigas }\end{array}$ & $\begin{array}{c}\text { Mytilus } \\
\text { galloprovincialis }\end{array}$ & Pecten spp. & 80856 & 69506 & 66430 & 95.57 & 1985 & 2.86 & 658 & 0.95 \\
\hline $\begin{array}{l}\text { Magallana } \\
\text { gigas }\end{array}$ & Pecten spp. & $\begin{array}{c}\text { Mytilus } \\
\text { galloprovincialis }\end{array}$ & 89552 & 76669 & 73114 & 95.36 & 2182 & 2.85 & 894 & 1.17 \\
\hline Pecten spp. & $\begin{array}{l}\text { Magallana } \\
\text { gigas }\end{array}$ & $\begin{array}{c}\text { Mytilus } \\
\text { galloprovincialis }\end{array}$ & 88971 & 69682 & 66291 & 95.13 & 1710 & 2.45 & 922 & 1.32 \\
\hline Pecten spp. & $\begin{array}{c}\text { Mytilus } \\
\text { galloprovincialis }\end{array}$ & $\begin{array}{l}\text { Magallana } \\
\text { gigas }\end{array}$ & 84085 & 65961 & 62434 & 94.65 & 2281 & 3.46 & 555 & 0.84 \\
\hline $\begin{array}{c}\text { Mytilus } \\
\text { galloprovincialis }\end{array}$ & Pecten spp. & $\begin{array}{l}\text { Magallana } \\
\text { gigas }\end{array}$ & 159737 & 147196 & 140147 & 95.21 & 4356 & 2.96 & 1478 & 1.00 \\
\hline $\begin{array}{c}\text { Mytilus } \\
\text { galloprovincialis }\end{array}$ & $\begin{array}{l}\text { Magallana } \\
\text { gigas }\end{array}$ & Pecten spp. & 147443 & 136629 & 130986 & 95.87 & 3304 & 2.42 & 1156 & 0.85 \\
\hline
\end{tabular}

In addition, we analyzed three DNA extract mixtures consisting of DNA from species belonging to one bivalve family (Table 5). The mixtures contained DNA from a scallop or mussel species, respectively. DNA from other bivalve species was present in a proportion of $1.0 \%$ each. Both species being present as main components, Placopecten magellanicus and Perna canaliculus, could be identified, with the number of reads assigned correctly ranging from 58156 to 77483 . However, quite different numbers of reads were correctly assigned to the minor components, ranging from 626 (Mizuhopecten yessoensis) to 50,391 (Mytilus galloprovincialis). Aequipecten opercularis was the only minor component that could not be detected. 
Table 5. Results for DNA extract mixtures representing one bivalve family. DNA from minor components was present in a proportion of $1 \%$ each. In addition, results for a DNA extract mixture containing DNA from a squid species (Sepiella inermis) as main component $(97.0 \%)$ and DNA from three bivalve species $(1 \%$ each) is shown. Numbers are mean values $(n=9$, three sequencing runs, three replicates per run).

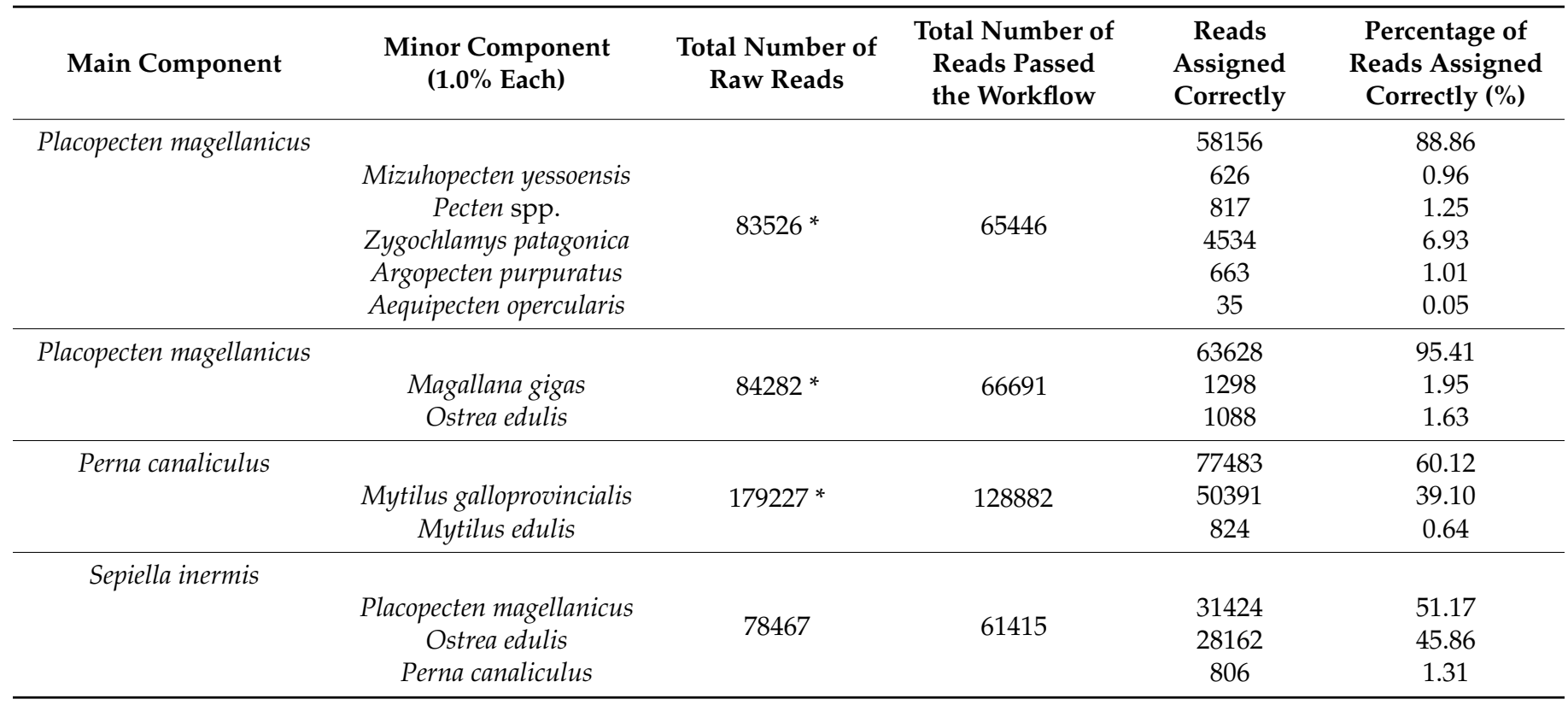

${ }^{*}$ Number of values ( $n=6$, three sequencing runs, two replicates per run).

We analyzed a further DNA extract mixture containing DNA from the squid species Sepiella inermis as main component $(97.0 \%)$ and DNA from the bivalve species Placopecten magellanicus, Ostrea edulis, and Perna canaliculus as minor components (1.0\% each). As expected, in this mixture, the main component could not be detected because the primers are not suitable for amplification of the target region for Sepiella inermis. 31424, 28162, and 806 reads, respectively, were assigned correctly to the three bivalve species.

In our previous metabarcoding study [47], individual DNA libraries were pooled in different ratios to achieve sufficient sequencing depth for minor components. The present study demonstrates, that minor components down to a proportion of $0.5 \%$ could be identified and differentiated although DNA libraries were pooled by mixing them in equal volumes. DNA extracts from reference samples and DNA extract mixtures most frequently resulted in less than 100,000 reads. However, for all samples on average $>75000$ raw reads were obtained, which turned out to be sufficient for reliable species identification.

\subsection{Analysis of Commercial Seafood Samples}

In order to investigate the applicability of the DNA metabarcoding method to foodstuffs, DNA extracts from 75 commercial food products were analyzed. According to declaration, eight samples (O1 and O4-O10) contained oyster species, 27 samples (M11, M14-M26, and M28-M40) mussel species, 15 samples (S41, S43-45, S48, S51-S55, and S56-S61) scallop species and 25 samples (Mi62-Mi86) were mixed-species seafood products (Table 6). The ingredient list of 30 out of 75 food products did not give any information on the bivalve species. A total of 39 samples were declared to contain "Crassostrea gigas", "Mytilus galloprovincialis", "Mytilus chilensis", "Mytilus edulis", "Zygochlamys patagonica", "Chlamys opercularis", "Placopecten magellanicus", "Pecten maximus", or "Patinopecten yessoensis". The remaining samples $(n=6)$ were labelled with "Mytilus spp." or "Pecten spp.". 
Table 6. Results obtained for commercial seafood samples. Samples listed above the double line were sequenced with the MiSeq $^{\circledR}$ (three sequencing runs, one replicate per run, numbers are mean values); samples listed below the double line were sequenced either with the MiSeq ${ }^{\circledR}$ or the iSeq ${ }^{\circledR}$.

\begin{tabular}{|c|c|c|c|c|c|c|c|}
\hline \multirow[b]{2}{*}{ Sample ID } & \multicolumn{2}{|c|}{ Declaration on the Product } & \multirow[b]{2}{*}{ Species Identified } & \multirow[b]{2}{*}{$\begin{array}{l}\text { Total Number } \\
\text { of Raw Reads }\end{array}$} & \multirow{2}{*}{$\begin{array}{c}\text { Total Number } \\
\text { of Reads } \\
\text { Passed the } \\
\text { Workflow }\end{array}$} & \multirow{2}{*}{$\begin{array}{l}\text { Reads } \\
\text { Assigned } \\
\text { Correctly }\end{array}$} & \multirow{2}{*}{$\begin{array}{l}\text { Percentage of } \\
\text { Reads Assigned } \\
\text { Correctly (\%) }\end{array}$} \\
\hline & $\begin{array}{l}\text { Scientific/Latin } \\
\text { Name }\end{array}$ & $\begin{array}{l}\text { Product } \\
\text { Description } \\
\text { [Eng] }\end{array}$ & & & & & \\
\hline O5 & Crassostrea gigas ${ }^{4}$ & $\begin{array}{c}\text { Oyster in } \\
\text { sunflower oil }\end{array}$ & Magallana gigas ${ }^{4}$ & $76930^{1}$ & 65728 & 64369 & 97.93 \\
\hline O6 & Crassostrea gigas ${ }^{4}$ & $\begin{array}{c}\text { Oyster in } \\
\text { sunflower oil }\end{array}$ & Magallana gigas ${ }^{4}$ & $44848^{1}$ & 38547 & 37610 & 97.57 \\
\hline O7 & Crassostrea gigas ${ }^{4}$ & Oyster in water & Magallana gigas ${ }^{4}$ & 76247 & 64917 & 63700 & 98.13 \\
\hline O8 & not declared & Oyster sauce & $\begin{array}{l}\text { Saccostrea malabonensis } \\
\text { Magallana bilineata }\end{array}$ & 14470 & 11658 & $\begin{array}{l}5442 \\
4652\end{array}$ & $\begin{array}{l}46.68 \\
39.91\end{array}$ \\
\hline M23 & not declared & $\begin{array}{l}\text { Mussel with } \\
\text { sherry vinegar }\end{array}$ & Mytilus galloprovincialis & 33517 & 30794 & 30358 & 98.58 \\
\hline M25 & not declared & $\begin{array}{c}\text { Mussel in } \\
\text { marinade sauce }\end{array}$ & Mytilus galloprovincialis & 163188 & 151688 & 150700 & 99.35 \\
\hline M26 & not declared & $\begin{array}{l}\text { Grilled blue } \\
\text { mussel }\end{array}$ & Mytilus galloprovincialis & 163106 & 151608 & 150433 & 99.23 \\
\hline M29 & $\begin{array}{l}\text { Mytilus } \\
\text { galloprovincialis }\end{array}$ & $\begin{array}{l}\text { Blue mussel in } \\
\text { tomato sauce }\end{array}$ & $\begin{array}{c}\text { Mytilus galloprovincialis } \\
\text { Mytilus edulis }\end{array}$ & 153435 & 140475 & $\begin{array}{c}132354 \\
7937\end{array}$ & $\begin{array}{c}94.22 \\
5.65\end{array}$ \\
\hline M30 & $\begin{array}{c}\text { Mytilus } \\
\text { galloprovincialis }\end{array}$ & $\begin{array}{c}\text { Blue mussel } \\
\text { A la mariniere }\end{array}$ & $\begin{array}{l}\text { Mytilus galloprovincialis } \\
\text { Mytilus edulis }\end{array}$ & 185479 & 171890 & $\begin{array}{c}170624 \\
1156\end{array}$ & $\begin{array}{c}99.26 \\
0.67\end{array}$ \\
\hline M31 & not declared & $\begin{array}{c}\text { Blue mussel in } \\
\text { organic } \\
\text { marinade }\end{array}$ & $\begin{array}{c}\text { Mytilus galloprovincialis } \\
\text { Mytilus edulis }\end{array}$ & 170303 & 158379 & $\begin{array}{c}157015 \\
1267\end{array}$ & $\begin{array}{c}99.14 \\
0.80\end{array}$ \\
\hline M32 & not declared & $\begin{array}{l}\text { Marinated blue } \\
\text { mussel }\end{array}$ & $\begin{array}{c}\text { Mytilus galloprovincialis } \\
\text { Mytilus edulis }\end{array}$ & 159181 & 144788 & $\begin{array}{c}143399 \\
1308\end{array}$ & $\begin{array}{c}99.04 \\
0.90\end{array}$ \\
\hline M33 & Mytilus chilensis & $\begin{array}{l}\text { Mussel in } \\
\text { Escabeche }\end{array}$ & $\begin{array}{c}\text { Mytilus galloprovincialis } \\
\text { Mytilus edulis }\end{array}$ & 167903 & 151219 & $\begin{array}{c}118879 \\
31737\end{array}$ & $\begin{array}{l}78.61 \\
20.99\end{array}$ \\
\hline M34 & Mytilus chilensis & Mussel & $\begin{array}{c}\text { Mytilus galloprovincialis } \\
\text { Mytilus edulis }\end{array}$ & 152112 & 138768 & $\begin{array}{l}87964 \\
49601 \\
\end{array}$ & $\begin{array}{l}63.39 \\
35.74 \\
\end{array}$ \\
\hline M36 & $\begin{array}{c}\text { Mytilus } \\
\text { galloprovincialis }\end{array}$ & $\begin{array}{l}\text { Blue mussel } \\
\text { marinated }\end{array}$ & $\begin{array}{c}\text { Mytilus galloprovincialis } \\
\text { Mytilus edulis }\end{array}$ & 176963 & 163721 & $\begin{array}{c}162224 \\
1323\end{array}$ & $\begin{array}{c}99.09 \\
0.81 \\
\end{array}$ \\
\hline M37 & Mytilus edulis & $\begin{array}{l}\text { Mussel in honey } \\
\text { mustard sauce }\end{array}$ & $\begin{array}{c}\text { Mytilus galloprovincialis } \\
\text { Mytilus edulis }\end{array}$ & 149364 & 136868 & $\begin{array}{c}135249 \\
1400\end{array}$ & $\begin{array}{c}98.82 \\
1.02 \\
\end{array}$ \\
\hline M38 & not declared & $\begin{array}{l}\text { Blue mussel } \\
\text { in marinade }\end{array}$ & $\begin{array}{c}\text { Mytilus galloprovincialis } \\
\text { Mytilus edulis }\end{array}$ & 138801 & 127244 & $\begin{array}{c}125980 \\
1056\end{array}$ & $\begin{array}{c}99.01 \\
0.83 \\
\end{array}$ \\
\hline S58 & not declared & $\begin{array}{c}\text { Rillettes de } \\
\text { Saint-Jacques }\end{array}$ & $\begin{array}{l}\text { Aequipecten opercularis } \\
\text { Mytilus galloprovincialis }\end{array}$ & 62787 & 44307 & $\begin{array}{c}42716 \\
1330\end{array}$ & $\begin{array}{c}96.41 \\
3.00 \\
\end{array}$ \\
\hline S59 & not declared & $\begin{array}{l}\text { Small scallop in } \\
\text { galician sauce }\end{array}$ & Aequipecten opercularis & 82550 & 59722 & 58296 & 97.61 \\
\hline Mi62 & Mytilus chilensis & Seafood mix & $\begin{array}{c}\text { Mytilus galloprovincialis } \\
\text { Mytilus edulis }\end{array}$ & 618324 & 569815 & $\begin{array}{l}433439 \\
134543 \\
\end{array}$ & $\begin{array}{l}76.07 \\
23.61\end{array}$ \\
\hline Mi63 & not declared & $\begin{array}{l}\text { Sauce with } \\
\text { seafood }\end{array}$ & $\begin{array}{c}\text { Mytilus edulis } \\
\text { Mytilus galloprovincialis }\end{array}$ & 152170 & 139306 & $\begin{array}{l}73550 \\
64729 \\
\end{array}$ & $\begin{array}{l}52.80 \\
46.47\end{array}$ \\
\hline Mi64 & $\begin{array}{l}\text { Mytilus chilensis } \\
\text { Mytilus edulis }\end{array}$ & Seafood mix & $\begin{array}{c}\text { Mytilus galloprovincialis } \\
\text { Mytilus edulis }\end{array}$ & 131285 & 119350 & $\begin{array}{l}81590 \\
37211\end{array}$ & $\begin{array}{l}68.36 \\
31.18\end{array}$ \\
\hline Mi65 & not declared & $\begin{array}{l}\text { Bouillabaisse } \\
\text { Marseille }\end{array}$ & $\begin{array}{c}\text { Mytilus } \\
\text { galloprovincialisMytilus edulis }\end{array}$ & 157311 & 143479 & $\begin{array}{c}138535 \\
4777 \\
\end{array}$ & $\begin{array}{c}96.55 \\
3.33 \\
\end{array}$ \\
\hline Mi66 & Mytilus chilensis & Seafood mix & $\begin{array}{c}\text { Mytilus galloprovincialis } \\
\text { Mytilus edulis }\end{array}$ & 152535 & 140047 & $\begin{array}{l}92024 \\
47415 \\
\end{array}$ & $\begin{array}{l}65.71 \\
33.86\end{array}$ \\
\hline Mi67 & Mytilus spp. & Seafood mix & $\begin{array}{c}\text { Mytilus galloprovincialis } \\
\text { Mytilus edulis }\end{array}$ & 76544 & 69081 & $\begin{array}{l}48275 \\
20459\end{array}$ & $\begin{array}{l}69.88 \\
29.62\end{array}$ \\
\hline Mi68 & $\begin{array}{c}\text { Mytilus } \\
\text { galloprovincialis }\end{array}$ & $\begin{array}{l}\text { Sea fruit salad in } \\
\text { sunflower oil }\end{array}$ & $\begin{array}{c}\text { Mytilus galloprovincialis } \\
\text { Mytilus edulis }\end{array}$ & 157861 & 145671 & $\begin{array}{c}144468 \\
1046\end{array}$ & $\begin{array}{c}99.17 \\
0.72 \\
\end{array}$ \\
\hline Mi69 & Mytilus chilensis & Seafood mix & $\begin{array}{c}\text { Mytilus galloprovincialis } \\
\text { Mytilus edulis }\end{array}$ & 140227 & 128007 & $\begin{array}{l}85679 \\
41686\end{array}$ & $\begin{array}{l}66.93 \\
32.57\end{array}$ \\
\hline Mi70 & not declared & $\begin{array}{l}\text { Sea fruit salad } \\
\text { fantasy }\end{array}$ & $\begin{array}{c}\text { Mytilus galloprovincialis } \\
\text { Mytilus edulis }\end{array}$ & 120677 & 106674 & $\begin{array}{c}101121 \\
5413\end{array}$ & $\begin{array}{c}94.80 \\
5.07 \\
\end{array}$ \\
\hline Mi71 & not declared & Seafood mix & $\begin{array}{c}\text { Mytilus galloprovincialis } \\
\text { Mytilus edulis }\end{array}$ & 160546 & 147278 & $\begin{array}{l}79680 \\
66675\end{array}$ & $\begin{array}{l}54.10 \\
45.27\end{array}$ \\
\hline
\end{tabular}


Table 6. Cont

\begin{tabular}{|c|c|c|c|c|c|c|c|}
\hline \multirow[b]{2}{*}{ Sample ID } & \multicolumn{2}{|c|}{ Declaration on the Product } & \multirow[b]{2}{*}{ Species Identified } & \multirow[b]{2}{*}{$\begin{array}{l}\text { Total Number } \\
\text { of Raw Reads }\end{array}$} & \multirow{2}{*}{$\begin{array}{l}\text { Total Number } \\
\text { of Reads } \\
\text { Passed the } \\
\text { Workflow }\end{array}$} & \multirow{2}{*}{$\begin{array}{l}\text { Reads } \\
\text { Assigned } \\
\text { Correctly }\end{array}$} & \multirow{2}{*}{$\begin{array}{l}\text { Percentage of } \\
\text { Reads Assigned } \\
\text { Correctly (\%) }\end{array}$} \\
\hline & $\begin{array}{l}\text { Scientific/Latin } \\
\text { Name }\end{array}$ & $\begin{array}{c}\text { Product } \\
\text { Description } \\
\text { [Eng] }\end{array}$ & & & & & \\
\hline Mi72 & Mytilus chilensis & Seafood mix & $\begin{array}{c}\text { Mytilus galloprovincialis } \\
\text { Mytilus edulis }\end{array}$ & 160059 & 146539 & $\begin{array}{l}91557 \\
54271\end{array}$ & $\begin{array}{l}62.48 \\
37.03\end{array}$ \\
\hline Mi73 & not declared & Seafood mix & $\begin{array}{c}\text { Mytilus edulis } \\
\text { Mytilus galloprovincialis }\end{array}$ & 150500 & 137634 & $\begin{array}{l}78942 \\
57608\end{array}$ & $\begin{array}{l}57.36 \\
41.86\end{array}$ \\
\hline $\mathrm{Mi} 74$ & not declared & Seafood mix & $\begin{array}{c}\text { Mytilus galloprovincialis } \\
\text { Mytilus edulis }\end{array}$ & 168841 & 155701 & $\begin{array}{l}79035 \\
75612\end{array}$ & $\begin{array}{l}50.76 \\
48.56\end{array}$ \\
\hline Mi75 & not declared & $\begin{array}{l}\text { Pizza Frutti di } \\
\text { mare }\end{array}$ & $\begin{array}{c}\text { Mytilus galloprovincialis } \\
\text { Mytilus edulis }\end{array}$ & $181822^{1}$ & 172620 & $\begin{array}{l}95184 \\
71440\end{array}$ & $\begin{array}{l}55.14 \\
41.39\end{array}$ \\
\hline Mi76 & not declared & Paella & $\begin{array}{c}\text { Mytilus galloprovincialis } \\
\text { Mytilus edulis }\end{array}$ & 150431 & 139511 & $\begin{array}{c}138335 \\
1070\end{array}$ & $\begin{array}{c}99.16 \\
0.77\end{array}$ \\
\hline Mi77 & $\begin{array}{l}\text { Mytilus edulis, } \\
\text { Mytilus chilensis }\end{array}$ & Paella & $\begin{array}{c}\text { Mytilus galloprovincialis } \\
\text { Mytilus edulis }\end{array}$ & 141816 & 132092 & $\begin{array}{c}130768 \\
1242\end{array}$ & $\begin{array}{c}99.00 \\
0.94\end{array}$ \\
\hline Mi78 & Mytilus chilensis & Seafood all'Olio & $\begin{array}{c}\text { Mytilus galloprovincialis } \\
\text { Mytilus edulis }\end{array}$ & 134717 & 122906 & $\begin{array}{l}73482 \\
48774 \\
\end{array}$ & $\begin{array}{l}59.79 \\
39.68 \\
\end{array}$ \\
\hline Mi79 & Mytilus chilensis & Seafood mix & $\begin{array}{c}\text { Mytilus galloprovincialis } \\
\text { Mytilus edulis }\end{array}$ & 148773 & 137122 & $\begin{array}{l}73035 \\
63249 \\
\end{array}$ & $\begin{array}{l}53.26 \\
46.13\end{array}$ \\
\hline Mi80 & Mytilus chilensis & Seafood mix & $\begin{array}{l}\text { Mytilus galloprovincialis } \\
\text { Mytilus edulis }\end{array}$ & 136695 & 126608 & $\begin{array}{l}88130 \\
37970\end{array}$ & $\begin{array}{l}69.61 \\
29.99\end{array}$ \\
\hline Mi81 & not declared & Sea fruit salad & $\begin{array}{c}\text { Mytilus galloprovincialis } \\
\text { Mytilus edulis }\end{array}$ & 153499 & 142736 & $\begin{array}{c}141578 \\
1022 \\
\end{array}$ & $\begin{array}{c}99.19 \\
0.72 \\
\end{array}$ \\
\hline Mi82 & $\begin{array}{l}\text { Zygochlamys } \\
\text { patagonica } \\
\text { Chlamys } \\
\text { opercularis }\end{array}$ & Scallop terrine & Zygochlamys patagonica & 76554 & 59181 & 57329 & 96.87 \\
\hline Mi83 & not declared & $\begin{array}{c}\text { Terrine of } \\
\text { salmon } \\
\text { and great scallop }\end{array}$ & Pecten spp. & $96596^{1}$ & 76834 & 75476 & 98.23 \\
\hline Mi84 & Mytilus chilensis & Seafood mix & $\begin{array}{c}\text { Mytilus galloprovincialis } \\
\text { Mytilus edulis }\end{array}$ & 163885 & 150852 & $\begin{array}{c}124468 \\
25916\end{array}$ & $\begin{array}{l}82.51 \\
17.18\end{array}$ \\
\hline Mi85 & not declared & $\begin{array}{l}\text { Instant noodle } \\
\text { seafood, mild }\end{array}$ & Mytilus galloprovincialis & 15409 & 14118 & 13750 & 97.39 \\
\hline Mi86 & not declared & $\begin{array}{l}\text { Instant noodle } \\
\text { seafood, spicy }\end{array}$ & Mytilus galloprovincialis & 9787 & 8892 & 8473 & 95.29 \\
\hline $\mathrm{O} 1$ & Crassostrea gigas ${ }^{4}$ & Oyster & Magallana gigas ${ }^{4}$ & $139319^{2}$ & 134073 & 133493 & 99.57 \\
\hline $\mathrm{O} 4$ & not declared & Oyster & Magallana gigas & $46089^{2}$ & 40991 & 40279 & 98.26 \\
\hline O9 & not declared & Oyster sauce & & not evaluable $^{3}$ & & & \\
\hline $\mathrm{O} 10$ & not declared & Oyster sauce & & not evaluable $^{3}$ & & & \\
\hline M11 & Mytilus edulis & Mussel & Mytilus galloprovincialis & $23766^{2}$ & 22546 & 22147 & 98.23 \\
\hline M14 & Mytilus spp. & Blue mussel & $\begin{array}{c}\text { Mytilus galloprovincialis } \\
\text { Mytilus edulis }\end{array}$ & $126880^{2}$ & 119717 & $\begin{array}{l}79522 \\
39555\end{array}$ & $\begin{array}{l}66.42 \\
33.04\end{array}$ \\
\hline M15 & Mytilus spp & Blue mussel & Mytilus galloprovincialis & 227678 & 220699 & 220226 & 99.79 \\
\hline M16 & Mytilus edulis & Bouchot mussel & Mytilus galloprovincialis & $51292^{2}$ & 49604 & 48832 & 98.44 \\
\hline M17 & not declared & $\begin{array}{l}\text { Grilled blue } \\
\text { mussel }\end{array}$ & $\begin{array}{c}\text { Mytilus galloprovincialis } \\
\text { Mytilus edulis }\end{array}$ & $9888^{2}$ & 6750 & $\begin{array}{l}3956 \\
1998\end{array}$ & $\begin{array}{l}58.61 \\
29.60\end{array}$ \\
\hline M18 & Mytilus chilensis & Blue mussel & Mytilus galloprovincialis & $53710^{2}$ & 51670 & 50733 & 98.19 \\
\hline M19 & not declared & Blue mussel & Mytilus galloprovincialis & $57238^{2}$ & 54822 & 53829 & 98.19 \\
\hline M20 & Mytilus spp. & Blue mussel & Mytilus galloprovincialis & $72113^{2}$ & 69576 & 68969 & 99.13 \\
\hline M21 & Mytilus edulis & Mussel & Mytilus galloprovincialis & $51328^{2}$ & 49908 & 49459 & 99.10 \\
\hline M22 & $\begin{array}{c}\text { Mytilus } \\
\text { galloprovincialis }\end{array}$ & Blue mussel & $\begin{array}{c}\text { Mytilus galloprovincialis } \\
\text { Mytilus edulis }\end{array}$ & $115950^{2}$ & 110777 & $\begin{array}{c}109262 \\
1466\end{array}$ & $\begin{array}{c}98.63 \\
1.32\end{array}$ \\
\hline M24 & Mytilus chilensis & $\begin{array}{l}\text { Blue mussel in } \\
\text { tomato sauce }\end{array}$ & $\begin{array}{c}\text { Mytilus galloprovincialis } \\
\text { Mytilus edulis }\end{array}$ & $113942^{2}$ & 107150 & $\begin{array}{l}94449 \\
12505\end{array}$ & $\begin{array}{l}88.15 \\
11.67\end{array}$ \\
\hline M28 & not declared & $\begin{array}{l}\text { Dry cat food } \\
\text { with green } \\
\text { lipped mussel }\end{array}$ & $\begin{array}{c}\text { Pecten spp. } \\
\text { Mytilus galloprovincialis } \\
\text { Perna canaliculus }\end{array}$ & $128693^{3}$ & 126380 & $\begin{array}{c}79764 \\
40450 \\
4712\end{array}$ & $\begin{array}{c}63.11 \\
32.01 \\
3.73\end{array}$ \\
\hline M35 & Mytilus chilensis & $\begin{array}{l}\text { Mussel in } \\
\text { tomato sauce }\end{array}$ & Mytilus galloprovincialis & $197899^{3}$ & 190771 & 189540 & 99.35 \\
\hline M39 & Mytilus chilensis & Blue mussel & $\begin{array}{c}\text { Mytilus galloprovincialis } \\
\text { Mytilus edulis }\end{array}$ & $182612^{3}$ & 175982 & $\begin{array}{l}96502 \\
75204\end{array}$ & $\begin{array}{l}54.84 \\
42.73\end{array}$ \\
\hline M40 & Mytilus edulis & Blue mussel & Mytilus galloprovincialis & $182958^{3}$ & 179399 & 178024 & 99.23 \\
\hline
\end{tabular}


Table 6. Cont.

\begin{tabular}{|c|c|c|c|c|c|c|c|}
\hline \multirow[b]{2}{*}{ Sample ID } & \multicolumn{2}{|c|}{ Declaration on the Product } & \multirow[b]{2}{*}{ Species Identified } & \multirow[b]{2}{*}{$\begin{array}{l}\text { Total Number } \\
\text { of Raw Reads }\end{array}$} & \multirow{2}{*}{$\begin{array}{l}\text { Total Number } \\
\text { of Reads } \\
\text { Passed the } \\
\text { Workflow }\end{array}$} & \multirow{2}{*}{$\begin{array}{c}\text { Reads } \\
\text { Assigned } \\
\text { Correctly }\end{array}$} & \multirow{2}{*}{$\begin{array}{l}\text { Percentage of } \\
\text { Reads Assigned } \\
\text { Correctly (\%) }\end{array}$} \\
\hline & $\begin{array}{c}\text { Scientific/Latin } \\
\text { Name }\end{array}$ & $\begin{array}{l}\text { Product } \\
\text { Description } \\
\text { [Eng] }\end{array}$ & & & & & \\
\hline S41 & $\begin{array}{l}\text { Placopecten } \\
\text { magellanicus }\end{array}$ & Deep-sea scallop & Placopecten magellanicus & $143794^{2}$ & 132140 & 131583 & 99.58 \\
\hline $\mathrm{S} 43$ & Pecten maximus & Great scallop & Mizuhopecten yessoensis & $122156^{2}$ & 113706 & 113128 & 99.49 \\
\hline S44 & Pecten spp. & Great scallop & Mizuhopecten yessoensis & $2873135^{2}$ & 2718126 & 2717426 & 99.97 \\
\hline S45 & $\begin{array}{l}\text { Placopecten } \\
\text { magellanicus }\end{array}$ & Deep-sea scallop & Placopecten magellanicus & $111673^{2}$ & 107119 & 106632 & 99.55 \\
\hline $\mathrm{S} 48$ & $\begin{array}{l}\text { Patinopecten } \\
\text { yessoensis }\end{array}$ & $\begin{array}{l}\text { Great scallop/ } \\
\text { Yesso scallop }\end{array}$ & Mizuhopecten yessoensis & $47397^{2}$ & 41076 & 407873 & 99.51 \\
\hline S51 & not declared & Great scallop & Placopecten magellanicus & $51565^{2}$ & 45007 & 44915 & 99.80 \\
\hline S52 & $\begin{array}{l}\text { Patinopecten } \\
\text { yessoensis }\end{array}$ & Great scallop & Mizuhopecten yessoensis & $46673^{2}$ & 39769 & 39627 & 99.64 \\
\hline S53 & Pecten spp. & Great scallop & Mizuhopecten yessoensis & $42857^{2}$ & 36443 & 35265 & 96.77 \\
\hline S54 & $\begin{array}{l}\text { Placopecten } \\
\text { magellanicus }\end{array}$ & Great scallop & Placopecten magellanicus & $55475^{2}$ & 48703 & 47915 & 98.38 \\
\hline S56 & not declared & Great scallop & Placopecten magellanicus & $1268169^{3}$ & 1061137 & 1060653 & 99.95 \\
\hline S57 & $\begin{array}{l}\text { Placopecten } \\
\text { magellanicus }\end{array}$ & Great scallop & Pecten spp. & $174497^{3}$ & 171299 & 170404 & 99.48 \\
\hline S60 & not declared & Deep-sea scallop & Placopecten magellanicus & $364474^{3}$ & 350953 & 350869 & 99.98 \\
\hline S61 & $\begin{array}{l}\text { Patinopecten } \\
\text { yessoensis }\end{array}$ & Great scallop & Mizuhopecten yessoensis & $159145^{3}$ & 152930 & 152849 & 99.95 \\
\hline
\end{tabular}

${ }^{1}$ Mean of two replicates; ${ }^{2}$ samples were analyzed with the MiSeq ${ }^{\circledR}$ instrument; ${ }^{3}$ samples were analyzed with the iSeq ${ }^{\circledR}$ instrument;

4 former nomenclature, synonym for Magallana gigas.

Our results indicate that DNA metabarcoding by targeting the $16 \mathrm{~S}$ rDNA barcode region of about $150 \mathrm{bp}$ in length is applicable to complex and highly processed foodstuffs. The barcode region could be amplified and sequenced even in products such as Bouillabaisse, Paella, and instant noodle seafood. Oyster sauce was the only sample matrix for which PCR amplification and consequently sequencing failed. Failure of obtaining PCR products for oyster sauce has already been reported by Chin Chin et al. [50], most probably caused by excessive DNA fragmentation due to industrial processing.

Three oyster species (Saccostrea malabonensis, Magallana bilineata, Magallana gigas), three mussel species (Mytilus galloprovincialis, Mytilus edulis, Perna canaliculus), and three scallop species (Aequipecten opercularis, Placopecten magellanicus, Pecten spp.) were detected in food products (O4, O8, M17, M19, M23, M25, M26, M28, M31, M32, M35, M38-M40, S51, S56, S58-S60, Mi63, Mi65, Mi70, Mi71, Mi73-Mi76, Mi81, Mi83, Mi85, and Mi86) although they were not declared on the label.

In each of the six oyster products that could be subjected to sequencing $(\mathrm{O} 1, \mathrm{O} 4-\mathrm{O} 8)$, Magallana gigas was identified. Magallana gigas is by far the predominant oyster species farmed in the EU [59].

In 21 products (M11, M16, M18, M21, M24, M33-M35, M37, M39, M40, Mi62, Mi64, Mi66, Mi69, Mi72, Mi77-Mi80, and Mi84), the mussel species Mytilus galloprovincialis was detected. In addition to Mytilus galloprovincialis, Mytilus edulis was identified (percentage of reads assigned correctly >1\%) in 13 products (M24, M33, M34, M39, Mi62, Mi64, Mi66, Mi69, Mi72, Mi78-Mi80, and Mi84). In four products, Mytilus edulis could not be detected although it was declared on the label. Mytilus galloprovincialis and Mytilus edulis are the two mussel species most frequently cultivated in European mussel farms [59]. In none of the products declared to contain Mytilus chilensis, Mytilus chilensis was detected. Instead of Mytilus chilensis, imported to EU countries from Chile [60], Mytilus galloprovincialis and/or Mytilus edulis were identified. According to the multi-species sequence alignment shown in Figure 1, the barcode region should allow distinguishing the three Mytilus species.

Placopecten magellanicus and Patinopecten yessoensis were listed as ingredients in samples S41, S45, S54, and S57 and samples S48, S52, and S61, respectively. Our results 
confirmed the presence of these two species, except for sample S57. In sample S43, declared to contain Pecten maximus, the species Mizuhopecten yessoensis was detected. In sample S44 and S53, declared as Pecten spp., the species Mizuhopecten yessoensis was also identified. In line with previous studies, most products declared to contain "Jakobsmuschel" did not contain a species of the genus Pecten $[15,18,19]$. Instead, we identified Placopecten magellanicus or Mizuhopecten yessoensis.

\section{Conclusions}

The DNA metabarcoding method developed in this study allows the detection of species of Mytilidae (mussels), Pectinidae (scallops), and Ostreidae (oysters), the most important bivalve families for human consumption. By combining three forward and four reverse primers in a triplex PCR assay, the barcode region, a fragment of mitochondrial $16 \mathrm{~S}$ rDNA, could be amplified in the species of interest.

The applicability of the novel DNA metabarcoding method was investigated by analyzing individual DNA extracts from eleven reference samples, ten DNA extract mixtures and DNA extracts from 75 commercial food products. In each of the eleven reference samples, the bivalve species was identified correctly. In DNA extract mixtures, not only the main component but also the minor components were detected correctly, with just a few exceptions. The analysis of commercial seafood products showed that the DNA metabarcoding method is applicable to complex and processed foodstuffs, allowing the identification of bivalves in, e.g., marinated form, in sauces, in seafood mixes and even in instant noodle seafood.

The DNA metabarcoding method runs on both the MiSeq ${ }^{\circledR}$ and iSeq ${ }^{\circledR}$ instrument of Illumina. Due to the compatibility of PCR and sequencing parameters, the DNA metabarcoding method can be combined with a DNA metabarcoding method for mammalian and poultry species published recently.

\section{Patent}

This manuscript has been submitted for grant of a European patent (application number: EP21204456.4).

Supplementary Materials: The following are available online at https:/ / www.mdpi.com/article/10 .3390 / foods10112618/s1, Supplementary Table S1: Declaration, origin and processing condition of the 86 food products, Supplementary Table S2: Sequences included into the reverence database, Supplementary Figure S1: Multi-species sequence alignment of the mitochondrial 16S rDNA barcoding region for the bivalve species of interest.

Author Contributions: Conceptualization, R.H. and S.D.; methodology, K.G., M.C.-M., M.W., R.H., S.D. and V.P.; software, S.D.; formal analysis, K.G. and S.D.; investigation, K.G. and S.D.; resources, K.G.; data curation, K.G. and S.D.; writing—original draft preparation, K.G.; writing-review and editing, A.L., M.C.-M., M.W., R.H., S.D. and V.P.; visualization, K.G.; supervision, M.C.-M., M.W., R.H., S.D. and V.P.; project administration, R.H. and S.D.; funding acquisition, A.L. and V.P. All authors have read and agreed to the published version of the manuscript.

Funding: This research was funded within a research project of the Austrian Competence Centre for Feed and Food Quality, Safety and Innovation (FFoQSI GmbH). The COMET-K1 competence centre FFoQSI is funded by the Austrian ministries BMK, BMDW and the Austrian provinces Lower Austria, Upper Austria and Vienna within the scope of COMET-Competence Centers for Excellent Technologies. The programme COMET is handled by the Austrian Research Promotion Agency FFG.

Data Availability Statement: The datasets generated for this study are available on request to the corresponding author.

Acknowledgments: This research was supported by the Austrian Agency for Health and Food Safety (AGES), Institute for Food Safety Vienna, Department for Molecular Biology and Microbiology and by LVA $\mathrm{GmbH}$ in cooperation with the University of Vienna and the University of Veterinary Medicine Vienna.

Conflicts of Interest: The authors declare no conflict of interest. 


\section{References}

1. Telahigue, K.; Chetoui, I.; Rabeh, I.; Romdhane, M.S.; El Cafsi, M. Comparative fatty acid profiles in edible parts of wild scallops from the Tunisian coast. Food Chem. 2010, 122, 744-746. [CrossRef]

2. Tan, K.; Ma, H.; Li, S.; Zheng, H. Bivalves as future source of sustainable natural omega-3 polyunsaturated fatty acids. Food Chem. 2020, 311, 125907. [CrossRef]

3. Manthey-Karl, M.; Lehmann, I.; Ostermeyer, U.; Rehbein, H.; Schröder, U. Meat Composition and Quality Assessment of King Scallops (Pecten maximus) and Frozen Atlantic Sea Scallops (Placopecten magellanicus) on a Retail Level. Foods 2015, 4, 524-546. [CrossRef]

4. Grienke, U.; Silke, J.; Tasdemir, D. Bioactive compounds from marine mussels and their effects on human health. Food Chem. 2014, 142, 48-60. [CrossRef]

5. Willer, D.F.; Aldridge, D.C. Sustainable bivalve farming can deliver food security in the tropics. Nat. Food 2020, 1, 384-388. [CrossRef]

6. World Register of Marine Species. Available online: http://www.marinespecies.org/index.php (accessed on 12 December 2020).

7. Food and Agricultural Organization of the United Nations (FAO). Fishery and Aquaculture Statistics. Global Aquaculture Production. Software for Fishery Statistical Time Series. Version FishStatJ v4.01.4. Available online: www.fao.org/fishery/statistics/ software/fishstatj/en (accessed on 10 June 2021).

8. European Parliament and of the Council. Regulation (EU) No. 1379/2013 of the European Parliament and of the Council of 11 December 2013 on the common organisation of the markets in fishery and aquaculture products, amending Council Regulations (EC) No 1184/2006 and (EC) No 1224/2009 and repealing Council Regulation (EC) No 104/2000. Off. J. Eur. Union 2013, L 354, $1-21$.

9. European Parliament and of the Council. Regulation (EU) No 1169/2011 of the European Parliament and of the Council of 25 October 2011 on the provision of food information to consumers, amending Regulations (EC) No 1924/2006 and (EC) No 1925/2006 of the European Parliament and of the Council, and repealing Commission Directive 87/250/EEC, Council Directive 90/496/EEC, Commission Directive 1999/10/EC, Directive 2000/13/EC of the European Parliament and of the Council, Commission Directives 2002/67/EC and 2008/5/EC and Commission Regulation (EC) No 608/2004. Off. J. Eur. Union 2011, L 304, 18-63.

10. Oceana; Protectin the World's Oceans. Available online: https:/ /oceana.org/publications/reports/one-name-one-fish-whyseafood-names-matter (accessed on 30 April 2021).

11. Rodríguez, E.M.; Ortea, I. Food authentication of seafood species. In Proteomics in Food Science: From Farm to Fork, 3rd ed.; Colgrave, M.L., Ed.; Academic Press: London, UK, 2017; pp. 331-342. ISBN 9780128040072.

12. Parrondo, M.; López, S.; Aparicio-Valencia, A.; Fueyo, A.; Quintanilla-García, P.; Arias, A.; Borrell, Y.J. Almost never you get what you pay for: Widespread mislabeling of commercial "zamburiñas" in northern Spain. Food Control 2021, 120, 107541. [CrossRef]

13. Giusti, A.; Tosi, F.; Tinacci, L.; Guardone, L.; Corti, I.; Arcangeli, G.; Armani, A. Mussels (Mytilus spp.) products authentication: A case study on the Italian market confirms issues in species identification and arises concern on commercial names attribution. Food Control 2020, 118, 107379. [CrossRef]

14. Harris, D.J.; Rosado, D.; Xavier, R. DNA Barcoding Reveals Extensive Mislabeling in Seafood Sold in Portuguese Supermarkets. J. Aquat. Food Prod. Technol. 2016, 25, 1375-1380. [CrossRef]

15. Näumann, G.; Stumme, B.; Rehbein, H. Differenzierung von Kammmuscheln durch DNA-Analyse. Inf. Aus Der FischereiforschungInf. Fish. Res. 2012, 59, 1-7. [CrossRef]

16. Espiñeira, M.; González-Lavín, N.; Vieites, J.M.; Santaclara, F.J. Development of a method for the genetic identification of commercial bivalve species based on mitochondrial 18S rRNA sequences. J. Agric. Food Chem. 2009, 57, 495-502. [CrossRef]

17. Guardone, L.; Tinacci, L.; Costanzo, F.; Azzarelli, D.; D’Amico, P.; Tasselli, G.; Magni, A.; Guidi, A.; Nucera, D.; Armani, A. DNA barcoding as a tool for detecting mislabeling of fishery products imported from third countries: An official survey conducted at the Border Inspection Post of Livorno-Pisa (Italy). Food Control 2017, 80, 204-216. [CrossRef]

18. Klapper, R.; Schröder, U. Verification of authenticity: A rapid identification method for commercial scallop species through multiplex real-time PCR. Food Control 2021, 121, 107574. [CrossRef]

19. Stephan, R.; Johler, S.; Oesterle, N.; Näumann, G.; Vogel, G.; Pflüger, V. Rapid and reliable species identification of scallops by MALDI-TOF mass spectrometry. Food Control 2014, 46, 6-9. [CrossRef]

20. Fernández, A.; García, T.; Asensio, L.; Rodríguez, M.Á.; González, I.; Céspedes, A.; Hernández, P.E.; Martín, R. Identification of the clam species Ruditapes decussatus (Grooved carpet shell), Venerupis pullastra (Pullet carpet shell), and Ruditapes philippinarum (Japanese carpet shell) by PCR-RFLP. J. Agric. Food Chem. 2000, 48, 3336-3341. [CrossRef]

21. Galimberti, A.; de Mattia, F.; Losa, A.; Bruni, I.; Federici, S.; Casiraghi, M.; Martellos, S.; Labra, M. DNA barcoding as a new tool for food traceability. Food Res. Int. 2013, 50, 55-63. [CrossRef]

22. Littlefair, J.E.; Clare, E.L. Barcoding the food chain: From Sanger to high-throughput sequencing. Genome 2016, 59, 946-958. [CrossRef]

23. Böhme, K.; Calo-Mata, P.; Barros-Velázquez, J.; Ortea, I. Review of Recent DNA-Based Methods for Main Food-Authentication Topics. J. Agric. Food Chem. 2019, 67, 3854-3864. [CrossRef]

24. Hebert, P.D.N.; Cywinska, A.; Ball, S.L.; deWaard, J.R. Biological identifications through DNA barcodes. Proc. Biol. Sci. 2003, 270, 313-321. [CrossRef] 
25. Teletchea, F.; Maudet, C.; Hänni, C. Food and forensic molecular identification: Update and challenges. Trends Biotechnol. 2005, 23, 359-366. [CrossRef] [PubMed]

26. Staats, M.; Arulandhu, A.J.; Gravendeel, B.; Holst-Jensen, A.; Scholtens, I.; Peelen, T.; Prins, T.W.; Kok, E. Advances in DNA metabarcoding for food and wildlife forensic species identification. Anal. Bioanal. Chem. 2016, 408, 4615-4630. [CrossRef] [PubMed]

27. Pollack, S.J.; Kawalek, M.D.; Williams-Hill, D.M.; Hellberg, R.S. Evaluation of DNA barcoding methodologies for the identification of fish species in cooked products. Food Control 2018, 84, 297-304. [CrossRef]

28. Armani, A.; Tinacci, L.; Lorenzetti, R.; Benvenuti, A.; Susini, F.; Gasperetti, L.; Ricci, E.; Guarducci, M.; Guidi, A. Is raw better? A multiple DNA barcoding approach (full and mini) based on mitochondrial and nuclear markers reveals low rates of misdescription in sushi products sold on the Italian market. Food Control 2017, 79, 126-133. [CrossRef]

29. Feng, Y.; Li, Q.; Kong, L.; Zheng, X. DNA barcoding and phylogenetic analysis of Pectinidae (Mollusca: Bivalvia) based on mitochondrial COI and 16S rRNA genes. Mol. Biol. Rep. 2011, 38, 291-299. [CrossRef]

30. Saavedra, C.; Peña, J.B. Phylogenetics of American scallops (Bivalvia: Pectinidae) based on partial 16S and 12S ribosomal RNA gene sequences. Mar. Biol. 2006, 150, 111-119. [CrossRef]

31. Fernandez, A.; García, T.; Gonzalez, I.; Asensio, L.; Rodriguez, M.Á.; Hernández, P.E.; Martin, R. Polymerase chain reactionrestriction fragment length polymorphism analysis of a $16 \mathrm{~S}$ rRNA gene fragment for authentication of four clam species. J. Food Prot. 2002, 65, 692-695. [CrossRef]

32. Bendezu, I.F.; Slater, J.W.; Carney, B.F. Identification of Mytilus spp. and Pecten maximus in Irish waters by standard PCR of the 18S rDNA gene and multiplex PCR of the 16S rDNA gene. Mar. Biotechnol. (NY) 2005, 7, 687-696. [CrossRef]

33. Colombo, F.; Trezzi, I.; Bernardi, C.; Cantoni, C.; Renon, P. A case of identification of pectinid scallop (Pecten jacobaeus, Pecten maximus) in a frozen and seasoned food product with PCR technique. Food Control 2004, 15, 527-529. [CrossRef]

34. Fernandes, T.J.R.; Amaral, J.S.; Mafra, I. DNA barcode markers applied to seafood authentication: An updated review. Crit. Rev. Food Sci. Nutr. 2020, 61, 1-32. [CrossRef]

35. Mafra, I.; Ferreira, I.M.P.L.V.O.; Oliveira, M.B.P.P. Food authentication by PCR-based methods. Eur. Food Res. Technol. 2008, 227, 649-665. [CrossRef]

36. Marín, A.; Fujimoto, T.; Arai, K. Rapid species identification of fresh and processed scallops by multiplex PCR. Food Control 2013, 32, 472-476. [CrossRef]

37. Marshall, H.D.; Johnstone, K.A.; Carr, S.M. Species-specific oligonucleotides and multiplex PCR for forensic discrimination of two species of scallops, Placopecten magellanicus and Chlamys islandica. Forensic Sci. Int. 2007, 167, 1-7. [CrossRef] [PubMed]

38. Zhan, A.; Hu, J.; Hu, X.; Lu, W.; Wang, M.; Peng, W.; Hui, M.; Bao, Z. Fast identification of scallop adductor muscles using species-specific microsatellite markers. Eur. Food Res. Technol. 2008, 227, 353-359. [CrossRef]

39. Meistertzheim, A.-L.; Héritier, L.; Lejart, M. High-Resolution Melting of $18 \mathrm{~S}$ rDNA sequences (18S-HRM) for discrimination of bivalve's species at early juvenile stage: Application to a spat survey. Mar. Biol. 2017, 164, 133-141. [CrossRef]

40. Pereira, A.M.; Fernández-Tajes, J.; Gaspar, M.B.; Méndez, J. Identification of the wedge clam Donax trunculus by a simple PCR technique. Food Control 2012, 23, 268-270. [CrossRef]

41. Jilberto, F.; Araneda, C.; Larraín, M.A. High resolution melting analysis for identification of commercially-important Mytilus species. Food Chem. 2017, 229, 716-720. [CrossRef]

42. Rego, I.; Martínez, A.; González-Tizón, A.; Vieites, J.; Leira, F.; Méndez, J. PCR technique for identification of mussel species. J. Agric. Food Chem. 2002, 50, 1780-1784. [CrossRef]

43. Jin, Y.; Li, Q.; Kong, L.; Yu, H.; Zhong, X. High-resolution melting (HRM) analysis: A highly sensitive alternative for the identification of commercially important Crassostrea oysters. J. Molluscan Stud. 2015, 81, 167-170. [CrossRef]

44. Hellberg, R.S.; Pollack, S.J.; Hanner, R.H. Seafood species identification using DNA sequencing. In Seafood Authenticity and Traceability; Academic Press: London, UK, 2016; pp. 113-132. ISBN 9780128015926.

45. Galimberti, A.; Casiraghi, M.; Bruni, I.; Guzzetti, L.; Cortis, P.; Berterame, N.M.; Labra, M. From DNA barcoding to personalized nutrition: The evolution of food traceability. Curr. Opin. Food Sci. 2019, 28, 41-48. [CrossRef]

46. Günther, B.; Raupach, M.J.; Knebelsberger, T. Full-length and mini-length DNA barcoding for the identification of seafood commercially traded in Germany. Food Control 2017, 73, 922-929. [CrossRef]

47. Dobrovolny, S.; Blaschitz, M.; Weinmaier, T.; Pechatschek, J.; Cichna-Markl, M.; Indra, A.; Hufnagl, P.; Hochegger, R. Development of a DNA metabarcoding method for the identification of fifteen mammalian and six poultry species in food. Food Chem. 2019, 272, 354-361. [CrossRef]

48. Frigerio, J.; Agostinetto, G.; Sandionigi, A.; Mezzasalma, V.; Berterame, N.M.; Casiraghi, M.; Labra, M.; Galimberti, A. The hidden 'plant side' of insect novel foods: A DNA-based assessment. Food Res. Int. 2020, 128, 108751. [CrossRef] [PubMed]

49. Nicolè, S.; Negrisolo, E.; Eccher, G.; Mantovani, R.; Patarnello, T.; Erickson, D.L.; Kress, W.J.; Barcaccia, G. DNA Barcoding as a Reliable Method for the Authentication of Commercial Seafood Products. Food Technol. Biotechnol. 2012, 50, $387-398$.

50. Chin Chin, T.; Adibah, A.B.; Danial Hariz, Z.A.; Siti Azizah, M.N. Detection of mislabelled seafood products in Malaysia by DNA barcoding: Improving transparency in food market. Food Control 2016, 64, 247-256. [CrossRef]

51. Giusti, A.; Armani, A.; Sotelo, C.G. Advances in the analysis of complex food matrices: Species identification in surimi-based products using Next Generation Sequencing technologies. PLoS ONE 2017, 12, e0185586. [CrossRef] 
52. Giusti, A.; Tinacci, L.; Sotelo, C.G.; Marchetti, M.; Guidi, A.; Zheng, W.; Armani, A. Seafood Identification in Multispecies Products: Assessment of 16SrRNA, cytb, and COI Universal Primers' Efficiency as a Preliminary Analytical Step for Setting up Metabarcoding Next-Generation Sequencing Techniques. J. Agric. Food Chem. 2017, 65, 2902-2912. [CrossRef]

53. Arulandhu, A.J.; Staats, M.; Hagelaar, R.; Voorhuijzen, M.M.; Prins, T.W.; Scholtens, I.; Costessi, A.; Duijsings, D.; Rechenmann, F.; Gaspar, F.B.; et al. Development and validation of a multi-locus DNA metabarcoding method to identify endangered species in complex samples. Gigascience 2017, 6, 1-18. [CrossRef] [PubMed]

54. Carvalho, D.C.; Palhares, R.M.; Drummond, M.G.; Gadanho, M. Food metagenomics: Next generation sequencing identifies species mixtures and mislabeling within highly processed cod products. Food Control 2017, 80, 183-186. [CrossRef]

55. Schirmer, M.; D’Amore, R.; Ijaz, U.Z.; Hall, N.; Quince, C. Illumina error profiles: Resolving fine-scale variation in metagenomic sequencing data. BMC Bioinform. 2016, 17, 125. [CrossRef] [PubMed]

56. Bundesministerium für Arbeit, Soziales, Gesundheit und Konsumentenschutz. Codexkapitel/B 35/Fische, Krebse, Weichtiere und dar-aus Hergestellte Erzeugnisse: BMGF-75210/0026-II/B/13/2017; Bundesministerium für Arbeit, Soziales, Gesundheit und Konsumentenschutz: Vienna, Austria, 2007.

57. Martin, M. Cutadapt removes adapter sequences from high-throughput sequencing reads. EMBnet J. 2011, 17, 10. [CrossRef]

58. Edgar, R.C. Search and clustering orders of magnitude faster than BLAST. Bioinformatics 2010, 26, 2460-2461. [CrossRef] [PubMed]

59. European Commission. Directorate General for Maritime Affairs and Fisheries. In The EU Fish Market; Publications Office: Brussels, Belgium, 2019.

60. Del Rio-Lavín, A.; Jiménez, E.; Pardo, M.Á. SYBR-Green real-time PCR assay with melting curve analysis for the rapid identification of Mytilus species in food samples. Food Control 2021, 130, 108257. [CrossRef] 